\title{
Nutritional Studies and Development of a Practical Feed for Milkfish (Chanos chanos) Culture in Zanzibar, Tanzania
}

\author{
J. J. Mwangamilo and N.S. Jiddawi \\ Institute of Marine Sciences, P.O. Box 668 Zanzibar, Tanzania
}

Key words: milkfish, Chanos chanos, feed, nutrition, growth, protein

\begin{abstract}
A study was conducted to find a suitable diet and feeding level for the culture of milkfish (Chanos chanos) in Zanzibar. Two growth trials and one digestibility trial were done. The first growth trial was conducted using 25,32 and $40 \%$ protein diets to determine the optimal level that could be used for the second growth trial on feeding levels. There were no significant differences on feed intake and growth performance of milkfish among the treatments $(\mathrm{P}<0.896)$. Body composition analysis showed that fish had more fat (lipid) when fed 32 than 25 and $40 \%$ protein diets. The digestibility of protein increased with increasing protein levels: it was 87.3, 92 and 93\% respectively. There were no significant differences among the diets $(\mathrm{P}<0.291)$. The $32 \%$ protein diet was chosen for the second growth trial to test a suitable feeding level. Milkfish were fed at $0,0.8,1.6,2.4,3.2$ and $4 \%$ of their body weight. There was a significant linear relationship $\left(\mathrm{r}^{2}=0.79\right)$ between digestible energy fed and energy gain, digestible protein fed and protein gain among protein and feeding levels. Protein and energy efficiency were 0.37 and 0.27 respectively. Results of growth, protein and energy efficiency and utilisation indicate that the suitable level of milkfish feeding was $4 \%$ of body weight per day when a $32 \%$ protein level was used.
\end{abstract}

\section{INTRODUCTION}

Worldwide the aquaculture industry has gained importance due to an increasing demand for fish to feed the world's increasing human population. In Tanzania, the demand for protein has also been rising steadily. This is due to declining fish landings and an increase in the prices of meat and similar animal protein, accompanied by a rise in living standards, and a thriving tourism industry. For these reasons there is a local need to introduce alternative sources of animal protein to supplement the natural harvest and reduce the fishing pressure. Fish farming is one way of increasing production.

In order to improve fish production, a detailed knowledge of the feed requirements of the fish along with information on their ability to utilise the protein and energy in the diet are needed. Feed accounts for the major portion of rearing costs (Boonyaratpalin, 1997) and it is desirable to formulate fish feed using locally available feed ingredients and locally available technology to ensure cost-effective aquaculture.

Dietary protein level and ration size can influence fish growth, feed efficiency and water quality. In earthen ponds, protein and energy are often limiting as standing crop of fish increases (Sumagaysay et al., 1991). The need for protein and other nutrients in supplemental diets depends upon the levels supplied by the natural food for a targeted production level. Thus, the incorporation of these nutrients in supplemental diets must increase to meet the requirement of increasing fish biomass (Sumagaysay \& Borlongan, 1995). In ponds and sea cages, where fish are largely dependent on artificial feeds, daily feed ration has

Corresponding author: NSJ.

E-mail: jiddawi@udsm.ac.tz 
to be estimated to reduce production cost, and to avoid loss of food and the pollution caused by uneaten feed (Sumagaysay, 1999).

Nutrient requirements in fish are normally quantified by a dose-response relationship, where diets containing graded levels of a nutrient are fed and the growth is measured (Lupatsch et al., 1998). Once the optimal requirement for a nutrient is determined this is provided in the feed.

Milkfish is a recent introduction (5 years) to aquaculture research in Tanzania. This is the second marine fish to be cultured experimentally in this country, the first being rabbitfish (Siganus canaliculatus), which was cultured in floating cages in the inshore waters of Zanzibar town, Unguja (Bwathondi, 1982). Also, the Institute of Marine Sciences (IMS), the Prison Department of Zanzibar and the National Centre for Mariculture in Israel, have developed a polyculture type of mariculture called the integrated mariculture pond system (IMPS) for use in Zanzibar (Mmochi et al., 2001). A working system is located at Makoba Bay, north of Zanzibar town and involves the culture of finfish (rabbitfish Siganus sp. and milkfish Chanos chanos), shellfish (Pinctada sp., Modiolus sp. and Isognomon sp.) and algae (Euchema sp. and Ulva sp.). The IMPS is based on the principle of feeding the fish a concentrated feed while the shellfish and algae use the plankton that develops in the fishpond and the nutrients left in the water by the fish respectively.

The primary goal of the study reported here was to determine the dietary needs of the milkfish for use in the Makoba Bay aquaculture project and to develop an appropriate feed to satisfy these needs. This diet should contribute to an economically sound culture operation in Zanzibar, thanks to its cost-effectiveness.

\section{MATERIALS AND METHODS}

\section{Study site}

The study was conducted at the Institute of Marine Sciences (IMS), Unguja (Fig.1, site 1). Fish were collceted from Makoba bay (Fig. 1, site 2) which is located on the North-West coast, approximately $35 \mathrm{~km}$ from Zanzibar town.

\section{Fish}

Milkfish (Chanos chanos) juveniles were collected from the brackish water at Makoba Bay, Unguja. The fish were transported to IMS by car, during which $88 \%$ survived. Fish were weighed 24 hours later and the individual fish weight was taken using a small field balance of $300 \mathrm{~g} \pm 0.1 \mathrm{~g}$ capacity. After weighing the fish were kept in experimental plastic tanks of 300-litre capacity each. The fish were not fed until the experiment started.

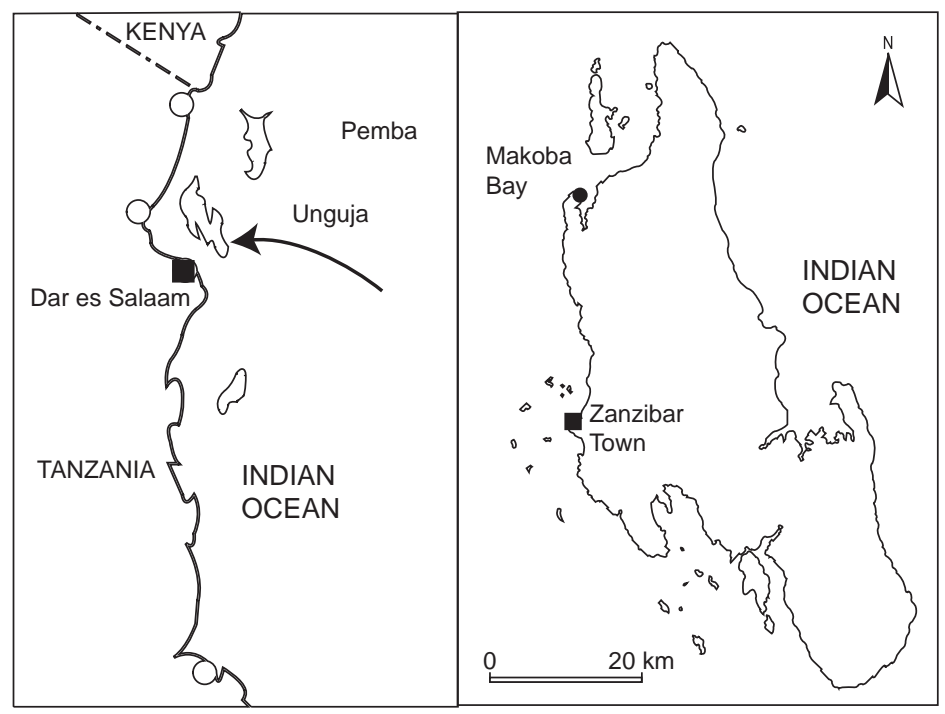

Fig. 1. Map of Unguja Island showing sample collection site, Makoba Bay 


\section{Diets}

All fish diets used in this research were formulated from feed ingredients that are readily available in Zanzibar. These included maize bran, broiler mash, fish meal (sardines), green algae (Ulva sp.) and coconut cake. The diet used was the one formulated earlier by Mmochi et al. (2001) with modification by trial and error method (Hardy, 1980), starting with balancing the protein followed by energy according to the composition of the ingredients as shown in Table 1.

\section{Proximate analysis}

The composition of ingredients was analysed at the National Centre for Mariculture of Israel as follows:

Dry matter content was calculated by weight loss after 24-hour drying at $105^{\circ} \mathrm{C}$. Crude protein content was measured using the Kjeldahl technique and multiplying $\mathrm{N}$ by 6.25 . Crude lipid content was measured after chloroform-ethanol extraction (Folch et al., 1957). Samples were homogenised with a high-speed homogeniser for 5 minutes and lipid content was determined gravimetrically after separation and vacuum drying. Ash content was calculated from the weight loss after incineration of samples for $24 \mathrm{~h}$ at $550{ }^{\circ} \mathrm{C}$ in a muffle furnace. Total phosphorus content was determined after ashing the samples and using the vanadomolybdate method. The resulting colour was measured on a spectrophotometer against a phosphorus standard at $435 \mathrm{~nm}$. Gross energy content was measured by combustion in a Parr bomb calorimeter using benzoic acid as a standard.

The ingredients were measured and mixed by hand according to the proportions shown in Table 1. Warm water was added as $48 \%$ of the diet and small balls were made and used to make pellets. Pellets measuring about $5 \mathrm{~mm}$ diameter and $3 \mathrm{~mm}$ length were made using an adjustable meat mincer and dried overnight in an oven at $60{ }^{\circ} \mathrm{C}$. After drying the diets were kept in dry and clean containers ready for feeding and analysis.

\section{Experimental setup}

The study was conducted from September 2001 to January 2002 in white plastic tanks of 300-1 each kept outdoors. Fresh seawater was pumped from the sea at high tide. Tanks containing fish were filled directly during pumping in addition to two more reserve tanks of 2000-litre capacity. Water was exchanged three times a week with about $90 \%$ of the water being replaced each time. Washing of tanks was done along with weighing of the fish to prevent development of algae that might be an alternative food.

Table 1. Formulation and composition of three diets (\%) for Chanos chanos experiment on protein levels

\begin{tabular}{|c|c|c|c|c|c|}
\hline \multirow[b]{2}{*}{ Ingredients } & \multirow{2}{*}{$\begin{array}{l}\text { Crude } \\
\text { protein }\end{array}$} & \multirow{2}{*}{$\begin{array}{c}\text { Energy } \\
\text { (cal/g) }\end{array}$} & \multicolumn{3}{|c|}{ Protein levels \% } \\
\hline & & & 25 & 32 & 40 \\
\hline Coconut cake & 24.0 & 4305 & 21 & 18 & 14 \\
\hline Sardines & 63.7 & 3777 & 18 & 32 & 49 \\
\hline Maize bran & 10.4 & 4424 & 21 & 18 & 14 \\
\hline Broiler mash & 16.9 & 4027 & 21 & 18 & 14 \\
\hline Ulva sp. & 12.0 & 3008 & 19 & 14 & 9 \\
\hline Total (\%) & & & 100 & 100 & 100 \\
\hline \multicolumn{6}{|c|}{ Proximate composition (\%) } \\
\hline Dry matter & & & 92.8 & 92.8 & 92.0 \\
\hline Crude protein & & & 24.1 & 30.2 & 34.4 \\
\hline Crude lipid & & & 6.6 & 7.1 & 6.9 \\
\hline Ash & & & 19.3 & 20.4 & 22.5 \\
\hline Phosphorus & & & 0.7 & 0.9 & 1.2 \\
\hline Energy $(\mathrm{kcal} / \mathrm{kg})$ & & & 3732 & 3704 & 3769 \\
\hline
\end{tabular}




\section{Digestibility determinations}

The digestibility trial was done separately alongside the above trials. Ten fish ranging from 40 to $60 \mathrm{~g}$ each were used for digestibility. The fish were kept in one tank and the abiotic conditions, setups and tank materials were the same as the two trials explained above. In each diet $8 \mathrm{~g}$ of chromic oxide $\left(\mathrm{Cr}_{2} \mathrm{O}_{3}\right)$ was mixed with $1 \mathrm{~kg}$ of feed (to give $0.8 \%$ concentration of $\mathrm{Cr}_{2} \mathrm{O}_{3}$ ). Chromium is an essential element for animals and it is involved in the activity of insulin in the body. The use of chromic oxide as an inert maker for digestibility in fish has been used in fish nutrition research for decades. No information is available on its toxicity to fish and it is used in very small concentration such the effect on the fish's health is negligible (George Wm. Kissil, pers. comm.). One diet after another was used and for each diet the experiment was run for 30 days. The fish were fed once daily and the faeces were collected every morning by siphoning from the tank. Faeces were then oven-dried at $50{ }^{\circ} \mathrm{C}$ for 5 hours and kept in a dry container for composition analysis.

\section{Growth trial 1 - Protein levels}

Three dietary treatments with different protein levels (25, 32 and 40\%) and equal energy (3700 $\mathrm{kcal} / \mathrm{kg}$ ) were formulated and fed to milkfish as shown in Table 1 . The fish were fed ad libitum three times daily, at 0900, 1300 and $1600 \mathrm{hrs}$. The whole experiment was set according to Table 2 .

\section{Growth trial 2 - Feeding levels}

The diet with $32 \%$ protein was used to test the feeding levels. The feeding levels were 0 (unfed), $0.8,1.6,2.4,3.2$ and $4 \%$ of their body weight as shown in Table 2. Feed was given once per day at a low feeding level and twice per day at the high level to make sure that all the food was consumed. The amount of feed was adjusted every 2 weeks based on the weight gain of the fish as determined by the weighings.

The effect of feeding on water quality was evaluated by measuring various parameters, namely temperature, $\mathrm{pH}$, oxygen and ammonia concentrations were measured twice throughout the experiment every 2 hours for 24 hours.

\section{Water quality}

Water quality parameters measured during the experiments were temperature, $\mathrm{pH}, \mathrm{NH}_{4}{ }^{+}$and dissolved oxygen concentrations. Temperature and oxygen concentration were measured using an oxygen meter, $\mathrm{pH}$ using $\mathrm{pH}$ meter and $\mathrm{NH}_{4}^{+}$using an ammonia kit (Merk 0C064653).

\section{Sample preparation}

Fish samples were taken from growth trials 1 and 2. In each trial an initial sample of 10 fish was randomly taken from each treatment before feeding experiment started. Additional samples of 10 fish each were taken from each replicate at the end of the experiment after 24 hours of starvation. These samples were used to determine body composition. Sampled fish were taken out of the water, put in sealed plastic bags and frozen immediately. Before analysis fish were cut into small pieces while frozen and ground using a meat grinder. The ground sample was dried at $60{ }^{\circ} \mathrm{C}$ for 2 days and the moisture content calculated from the weight loss. The remaining dried fish sample was mixed using a blender and kept in a refrigerator until analysis.

Table 2. Experimental setup for growth trials

\begin{tabular}{lll}
\hline & Protein levels (trial 1) & Feeding levels (trial 2) \\
\hline Fish & Chanos chanos & Chanos chanos \\
Number of fish per tank & 13 & 12 \\
Individual weight (g) range & $10-28$ & $10-28$ \\
Initial avg wt. (g) in tanks & $15-18$ & $12-18$ \\
Feeding level & ad libitum & $0,0.8,1.6,2.4,3.2$ and 4\% \\
Feeding & 3 times daily & 1 to 2 times daily \\
Replicates & 2 & No replicate \\
Duration & 64 days & 39 days \\
Average water temp. $\left({ }^{\circ} \mathrm{C}\right)$ & $25-29$ & $27-32$ \\
Weighing freq. $($ days $)$ & Every 14 & Every 14 days \\
\hline
\end{tabular}




\section{Sample analysis}

Samples were analysed for proximate composition, moisture content and digestibility. The same analytical method was applied to fish, feed and faeces samples. Dry matter, crude protein, crude lipid, ash, total phosphorus and gross energy content were measured the same way as feed ingredients. Chromic oxide was estimated by wet digestion. Food and faeces containing $\mathrm{Cr}_{2} \mathrm{O}_{3}$ were digested in a mixture of perchloric acid, concentrated sulphuric acid and sodium-molybdate at a temperature of $250{ }^{\circ} \mathrm{C}$. The resulting dichromate was determined at $360 \mathrm{~nm}$ against $\mathrm{Cr}_{2} \mathrm{O}_{7}$ standard solutions. Feed and body composition analyses were carried out at the National Centre for Mariculture in Eilat, Israel.

\section{Costing of ingredients and fish production}

Costs of diets were evaluated from a known amount of food eaten in grammes and the price of food in Tanzania shillings (Tshs) per kilogramme. The costs of fish production were calculcated using the market price of fish in relation to the weight gained by fish.

\section{Data analysis}

The concentration of the nutrients and the inert indicator were determined in the feed and faeces from digestibility trial. The apparent digestibility coefficient (ADC) of the nutrient was calculated according to the following formula:

Apparent digestibility $=$

$100-\frac{\% \text { indicator in food }}{\% \text { indicator in faeces }} \times \frac{\% \text { nutrient in faeces }}{\% \text { nutrient in food }} \times 100$

In growth trials the following calculations were made using the formulae indicated:

I - Daily feed consumption and fish weight gain during the experiments were measured to calculate:

(a) Daily food ration DFR $(\% /$ d $)=($ food $/$ day $) /$ body weight x 100 .

(b) Specific growth rate SGR $(\% /$ day $)=\ln \left(\mathrm{w}_{2} /\right.$ $\left.\mathrm{w}_{1}\right) / \Delta \mathrm{t} \times 100$ where $\mathrm{w}_{2}$ and $\mathrm{w}_{1}$ are final and initial average weights respectively and $\Delta \mathrm{t}$ is the number of days of growth. (c) Food conversion ratio FCR $=$ food intake/ weight gain.

II - Laboratory analyses combined with feed consumption and weight gain were used to calculate:

$\mathrm{ER}=\{$ (Final fish weight $\mathrm{x}$ final energy content $)$ - (Initial fish weight $x$ Initial energy content) $\}$ /

Total number of days, where $\mathrm{ER}=$ Energy retention in $\mathrm{cal} / \mathrm{g} /$ fish/day.

The same calculation was used for protein retention in $\mathrm{g} /$ fish/day.

III - Survival (\%) was estimated from the (number of fish at the end of experiment / total number of fish at the beginning) x 100 .

Descriptive statistics (arithmetic mean and standard deviation) were also used. Significant differences for the experiment on protein levels were statistically tested using a one-way ANOVA (Zar, 1984). Protein and energy utilisation and efficiency for the experiment on feeding levels was tested using regression analysis.

\section{RESULTS}

\section{Digestibility}

Results of digestibility of the three diets with different protein levels are shown in Table 3. Digestibility of protein and dry matter was lowest in the $25 \%$ protein diet and increased as the protein level increased in the remaining diets. The digestibility of phosphorus, energy, and organic matter did not change much among the treatments. One-Way ANOVA indicated no significant differences among the treatments $(\mathrm{F}=1.194, \mathrm{P}=$ 0.291 ) with regard to digestibility of any of the nutrients.

Table 3. Digestibility (\%) of the diets used in experiment on protein levels

\begin{tabular}{lccc}
\hline & \multicolumn{3}{c}{ Protein level of diet } \\
\cline { 2 - 4 } & $25 \%$ & $32 \%$ & $40 \%$ \\
\cline { 2 - 4 } Protein & 87.3 & 92.0 & 93.0 \\
Phosphorus & 77.1 & 78.4 & 77.9 \\
Dry matter & 67.9 & 70.2 & 72.5 \\
Energy & 85.1 & 84.8 & 89.9 \\
Organic matter & 79.8 & 79.5 & 84.4 \\
\hline
\end{tabular}




\section{Trial 1 - Protein levels}

Growth of milkfish fed three diets of different protein levels for 64 days are shown in Table 4. Food intake (\%/day) did not change among the treatments. One-way ANOVA indicated no significant differences on the initial average weight of the fish, and among weight gain, food conversion ratio (FCR) and specific growth rate ( $\mathrm{SGR}$ in \%/day) $(\mathrm{F}=0.821, \mathrm{P}=0.650)$ between the three treatments. Digestible energy and digestible protein available to the fish increased with increasing protein levels.

The body composition of milkfish (Chanos chanos) fed three different diets in this experiment is shown in Table 5. Crude protein, lipid, dry matter and energy were higher in the treatments than the initial fish sample (sample taken before feeding experiment started). Crude protein (\%) from the fish samples averaged 15.8, 18.8, 19.6 and 19.7 for the initial, 25, 32 and $40 \%$ diets respectively. Crude lipid (\%) was $1.4,4.9,5.1$, and 5.1, and energy (cal/g) averaged 1001.7, 1518, 1550, 1593 for initial, 25, 32 and $40 \%$ diets respectively. Statistically there were no significant differences (F-value=3.21, $\mathrm{P}=0.0561)$ among the nutrients.

\section{Trial 2 - Feeding levels}

The efficiency of protein and energy utilisation of milkfish (Chanos chanos) fed $32 \%$ diet with different feeding levels are shown in Figs $2 \mathrm{a}$ and $2 b$ respectively. The relationship between digestible protein fed and protein gain (mg/day/ fish) are presented as $\mathrm{x}$ and $\mathrm{y}$ respectively and is described by the linear regression $\mathrm{y}=0.37 \mathrm{x}-$

Table 4. Growth performance of Chanos chanos fed diets of three protein levels for 64 days

\begin{tabular}{|c|c|c|c|c|c|c|}
\hline \multirow{2}{*}{$\frac{\text { Diets }}{\text { Initial avg. body wt. (g/fish) }}$} & \multicolumn{2}{|c|}{$25 \%$} & \multicolumn{2}{|c|}{$32 \%$} & \multicolumn{2}{|c|}{$40 \%$} \\
\hline & $17.0 \pm 5.6$ & $17.8 \pm 4.6$ & 15. $2 \pm 3.4$ & $17.7 \pm 5.5$ & $15.5 \pm 5.7$ & $17.2 \pm 6.4$ \\
\hline Final avg. Body wt.(g/fish ) & $28.3 \pm 5.2$ & $28.1 \pm 4.9$ & $25.2 \pm 5.4$ & $29.6 \pm 4.6$ & $25.3 \pm 4.8$ & $27.5 \pm 4.4$ \\
\hline Food intake (\%/day) & 3.6 & 3.5 & 3.9 & 3.4 & 3.8 & 3.5 \\
\hline Weight gain (g/fish) & 11.3 & 10.2 & 10.1 & 11.9 & 9.7 & 10.4 \\
\hline FCR & 4.7 & 5.0 & 5.1 & 4.3 & 4.2 & 4.9 \\
\hline SGR (\%/day) & 0.8 & 0.7 & 0.8 & 0.8 & 0.9 & 0.7 \\
\hline $\mathrm{DE}^{1}(\mathrm{cal} / \mathrm{g})$ & 3089.7 & & 3141.0 & & 3391.3 & \\
\hline $\mathrm{DP}^{2}(\%)$ & 21.0 & & 27.8 & & 32.1 & \\
\hline PRV (mg/fish/day) & 43.3 & 36.8 & 39.0 & 47.7 & 39.8 & 41.8 \\
\hline ERV (cal/fish/day) & 94.6 & 94.4 & 87.9 & 106.8 & 110.1 & 98.8 \\
\hline Survival (\%) & 100 & 100 & 100 & 100 & $15^{\mathrm{N}}$ & 100 \\
\hline
\end{tabular}

Initial and final weight values represent the mean \pm SD of 13 individual fish. FCR, food conversion ratio; SGR, specific growth rate.; PRV = protein retention value; $E R V=$ energy retention value.

All values except for PRV, ERV, DE and DP represent the mean of 2 replicates.

${ }^{1}$ Digestible energy (DE) in the diet calculated as energy digestibility $x$ energy fed

${ }^{2}$ Digestible protein (DP) in the diet calculated as protein digestibility x protein fed.

${ }^{\mathrm{N}}$ Mortality in one of the tanks occurred 10 days before the end of this trial due to a power failure.

Table 5. Composition of milkfish (Chanos chanos) fed diets with three protein levels for 64 days

\begin{tabular}{lrrrrrrr}
\hline Treatments & Initial & \multicolumn{2}{c}{$25 \%$} & & \multirow{2}{*}{$32 \%$} & & \multirow{2}{*}{$40 \%$} \\
\hline Composition & & & & & & & \\
Crude protein (\%) & 15.8 & 19.3 & 18.4 & 19.4 & 19.8 & 19.8 & 19.5 \\
Crude lipid (\%) & 1.4 & 4.6 & 5.1 & 4.9 & 5.4 & 5.4 & 4.7 \\
Ash (\%) & 4.9 & 4.0 & 3.8 & 3.8 & 3.9 & 3.9 & 3.8 \\
Energy (cal/g) & 1001.7 & 1497.2 & 1538.7 & 1533.7 & 1566.3 & 1600.7 & 1585.7 \\
Phosphorus (\%) & 0.7 & 0.7 & 0.6 & 0.6 & 0.6 & 0.6 & 0.7 \\
Dry matter (\%) & 22.2 & 27.5 & 27.2 & 27.5 & 28.6 & 28.9 & 28.1 \\
\hline
\end{tabular}




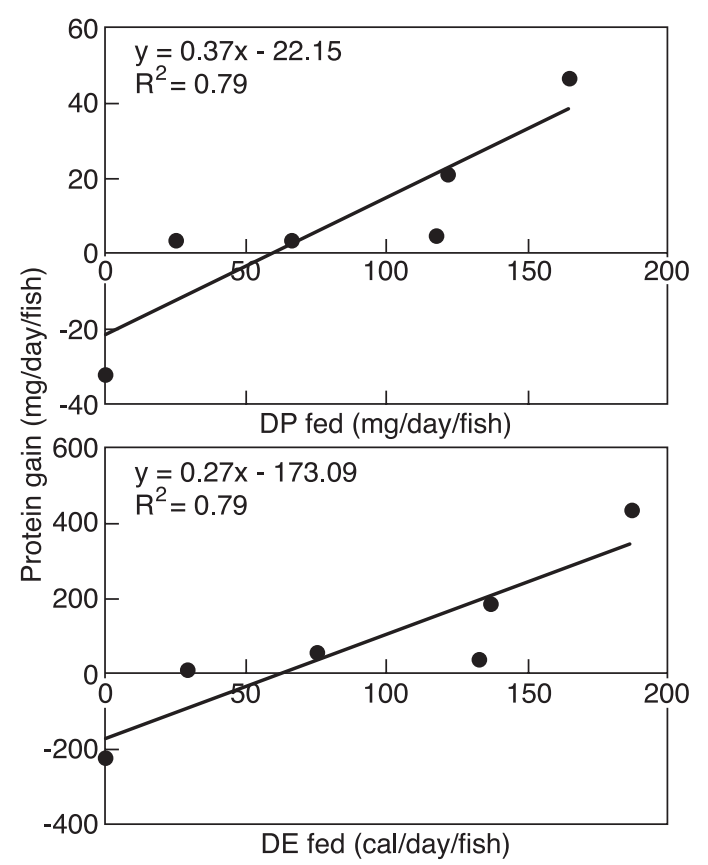

Fig. 2. Relationship between (a) digestible protein (DP) fed and protein gain (mg/day/fish) and (b) digestible energy (DE) fed and energy gain(cal/day/fish) in milkfish (Chanos chanos) fed increasing levels using the $32 \%$ diet in trial 2

22.15, $\mathrm{r}^{2}=0.79$ (Fig. 2a). There was a significant linear relationship between digestible protein fed and protein gain. The same relationship applied to $\mathrm{x}=$ energy fed and $\mathrm{y}=$ energy gain (cal/day/fish) is expressed by the linear equation $\mathrm{y}=0.27 \mathrm{x}-$ 173.09, $\mathrm{r}^{2}=0.79$ (Fig. 2b). There was a significant linear relationship between digestible energy fed and energy gain. The slopes of the lines are the efficiency of protein and energy utilisation for growth and are 0.37 and 0.27 respectively.

The protein and energy needed for maintenance (zero growth) are calculated from the two equations where the lines intercept the $\mathrm{x}$-axes. For energy 173.09/0.27 = 641.1 (cal/day/fish) and protein $22.15 / 0.37=59.9(\mathrm{mg} /$ day/fish $)$

\section{Water quality}

Water quality parameters measured were temperature, $\mathrm{pH}, \mathrm{NH}_{4}{ }^{+}$and dissolved oxygen. In the experiment on feeding levels, during the 24hour monitoring, temperature varied from 27.9$31.7^{\circ} \mathrm{C}$, dissolved oxygen from 71 to $108 \%$ (Fig. $3 \mathrm{a}$ ), $\mathrm{pH}$ varied from 7.62 to 8.46 (Fig. $3 \mathrm{~b}$ ), $\mathrm{NH}_{4}^{+}$ varied from 0 to $4.5 \mathrm{mg} / \mathrm{l}$ (Fig. 3c).

\section{Costings of ingredients and fish production}

Economic estimation of the diets showed that costs of feed increase with increasing protein levels whereas profit was slightly higher with a $32 \%$ protein diet compared to 25 and $40 \%$ (Table 6).

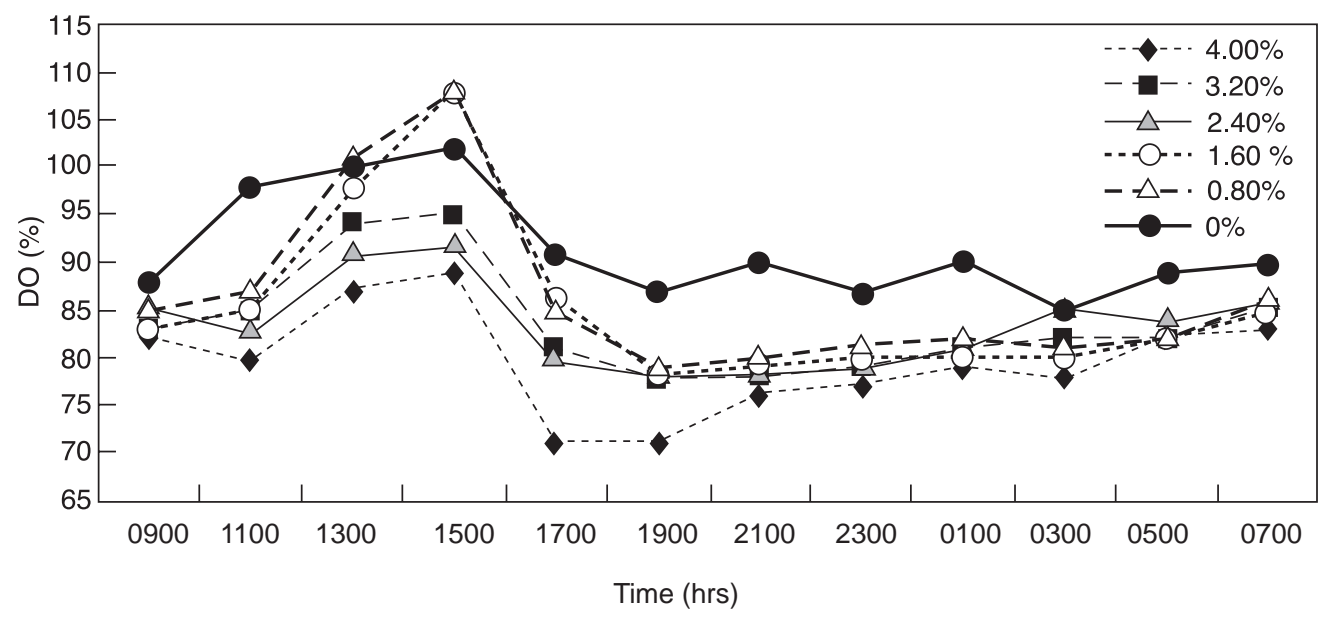

Fig. 3a. Dissolved oxygen (\%) measured 24 hours on the 17 December 2001 according to feeding levels using $32 \%$ protein diet 

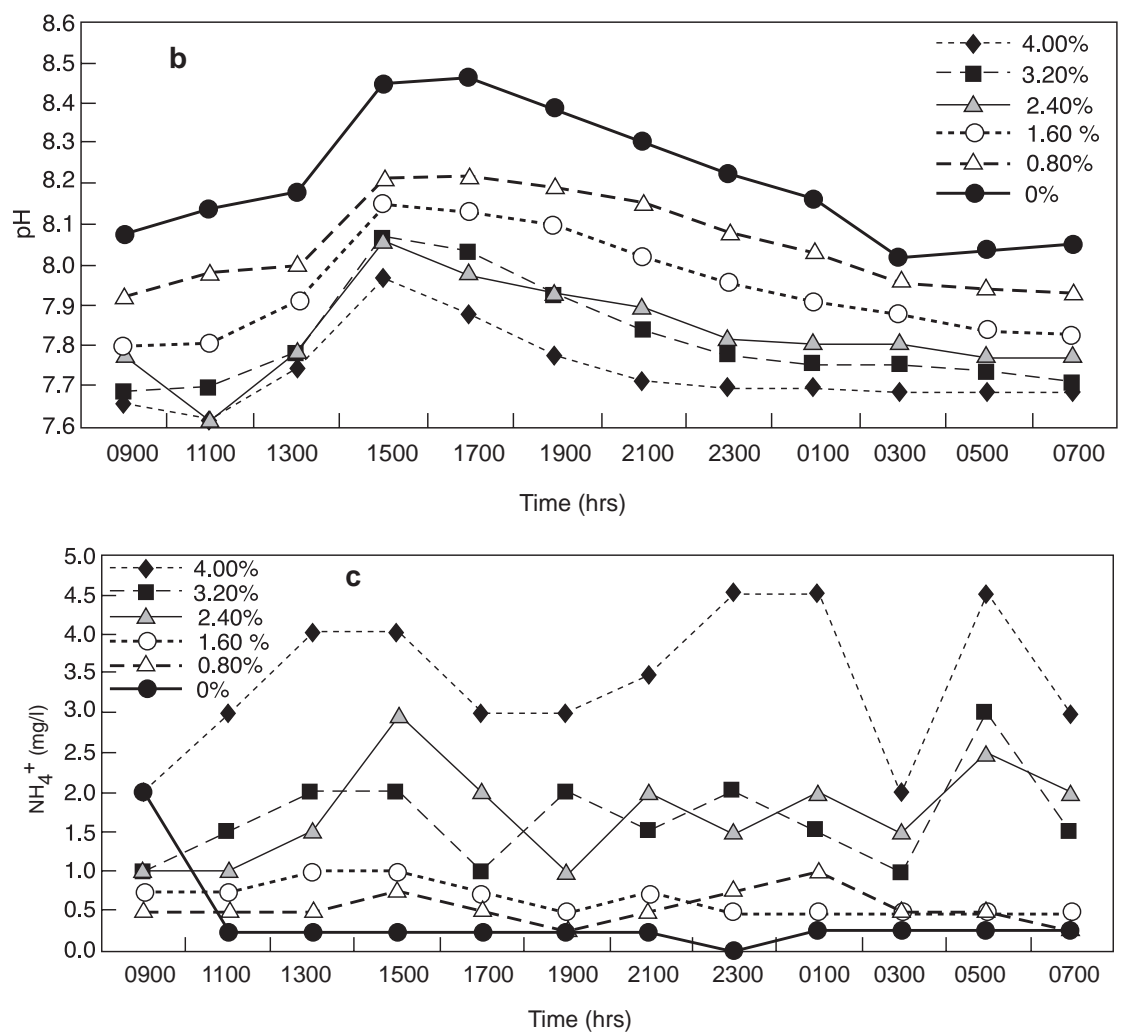

Fig. 3 (b) $\mathrm{pH}$ and (c) $\mathrm{NH}^{+}$measured for 24 hours on 17 December 2001 according to feeding levels using $32 \%$ protein diet

Table 6. Evaluation of the cost of the three diets and the cost of fish production

\begin{tabular}{lcrrrrrr}
\hline & & \multicolumn{3}{c}{$\begin{array}{c}\text { Fraction of ingredient } \\
(\%) \text { in diet }\end{array}$} & \multicolumn{3}{c}{$\begin{array}{c}\text { Ingredient cost for } \\
\text { each diet (Tsh/kg) }\end{array}$} \\
\cline { 3 - 8 } Ingredients & Cost (Tsh/kg) & $25 \%$ & $32 \%$ & $40 \%$ & $25 \%$ & $32 \%$ & $40 \%$ \\
\hline Coconut cake & 30 & 21 & 18 & 14 & 6.30 & 5.40 & 4.20 \\
Sardines & 450 & 18 & 32 & 49 & 81.00 & 144.00 & 220.50 \\
Broiler mash & 156 & 21 & 18 & 14 & 32.76 & 28.08 & 21.84 \\
Ulva & & 19 & 14 & 9 & 0 & 0 & 0 \\
Maize bran & 100 & 21 & 18 & 14 & 21.00 & 18.00 & 18.00 \\
Total & & $100 \%$ & $100 \%$ & $100 \%$ & 141.06 & 195.48 & 264.54 \\
\hline
\end{tabular}

Costs of production based on the weight gain and the price of milkfish in Zanzibar

\begin{tabular}{lcccccc}
\hline $\begin{array}{l}\text { Milkfish cost/ } \\
\text { kg (Tshs) }\end{array}$ & Diets & $\begin{array}{c}\text { Weight } \\
\text { gain (g/fish) }\end{array}$ & $\begin{array}{c}\text { Food } \\
\text { eaten }(\mathrm{g})\end{array}$ & $\begin{array}{c}\text { Cost of food } \\
\text { eaten }{ }^{1}(\text { Tsh) }\end{array}$ & $\begin{array}{c}\text { Production } \\
\text { (Tsh) }\end{array}$ & $\begin{array}{c}\text { Profit }^{3} \\
\text { (Tsh) }\end{array}$ \\
\hline 1500 & $25 \%$ & 10.3 & 52.07 & 7.35 & 200.85 & 193.5 \\
$1500 ?$ & $32 \%$ & 11.0 & 51.40 & 10.05 & 214.50 & 204.45 \\
1500 & $40 \%$ & 10.1 & 45.99 & 12.17 & 196.95 & 184.78 \\
\hline
\end{tabular}

${ }^{1}$ Costs of food (Tsh/kg) calculated from the amount of food eaten $(\mathrm{g}) \mathrm{x}$ the price of food per $\mathrm{kg} / 1000$.

${ }^{2}$ Production calculated from price of fish $(\mathrm{Tsh} / \mathrm{kg}) \mathrm{x}$ weight gain $(\mathrm{g} / \mathrm{fish}) \mathrm{x} 13$ fish.

${ }^{3}$ Profit (Tsh) calculated from the difference between the production and the costs of food.

NB: Only the costs of feed were considered, other costs were considered to be constant. 


\section{DISCUSSION}

\section{Digestibility}

Digestibility describes the fraction of the nutrients in the ingested feed that are not excreted in the faeces. The digestibility of protein in the three diets increased with increasing protein levels (Table 3). The digestibility difference between 32 and $40 \%$ was only $1 \%$ (92 and $93 \%$ respectively), but the difference between 25 and $32 \%$ was $5 \%$ (87 and $92 \%$ respectively). A $92 \%$ digestibility means that only $8 \%$ out of the dietary protein was not digestible. The more digestible the feed the less the nutrients left in the environment and the greater the tissue deposition (growth) in the fish. Likewise, by knowing the digestibility of ingredients it is easy to select the cheaper ones with higher digestibility for use in commercial feeds. Furthermore, digestibility helps in determination of the nutrient budget in order to increase cost effectiveness of the feed and to minimise the pollution to the pond environment (Sumagaysay, 1999).

\section{Growth trial 1 - Protein levels}

Energy retention increased with higher protein levels in the diets but protein retention, although statistically not significant, was better with $32 \%$ as compared with 25 and $40 \%$ protein levels. Food conversion ratio (FCR) is dry weight of feed per unit wet weight gain by the fish. However, the ratio in this study as shown in Table 4, was higher than expected (4.6-4.9) which may be due to a number of reasons. The poor values obtained from growth and FCR may be due to the limited number of tanks (replicates) used, the lack of a flow-through water system and the short duration of the experiment.

The composition of fish showed that crude protein, crude lipid, energy and dry matter were higher in fish fed all diets as compared to the initial fish samples, whereas ash and phosphorus content decreased (Table 5). Reduced ash in all treatments indicates that fish at the beginning had less fat (lipid) thus more ash.

The results of this research compare well with other findings. Borlongan \& Satoh (2001) stated that the phosphorus level required for optimal growth of juvenile milkfish is approximately
$0.85 \%$ of the dry diet. This compares favourably with the $0.89 \%$ phosphorus supplied at $32 \%$ protein level in the present study (See Table 1). Furthermore, the authors reported that crude protein and dry matter showed a tendency of increasing with the protein level whereas crude lipid was slightly higher in $32 \%$ than 25 and $40 \%$ protein level. This observation is in agreement with the present study (Table 4). In terms of profit or loss, the high protein diets are most likely to result in an economic loss. Sumagaysay et al. (1991) have demonstrated that any increase in dietary protein will result in an increase in the cost of feed as shown in Table 6. Labour costs were not considered although in some cases a higher protein diet can give a higher growth rate and the culture period can be shortened, which may result in higher production, as well as higher profits.

The results of fish growth, body composition and digestibility in this experiment together with supporting ideas from the literature (Sumagaysay, 1999) and the estimation of costs, show that the $32 \%$ protein diet was best for the culture of Chanos chanos in Zanzibar.

\section{Growth trial 2 - Feeding levels}

The feeding levels used in this research $(0,0.8$, 1.6, 2.4, 3.2 and 4\%) were estimated from the experiment on protein levels. The maximum feeding level obtained was $3.9 \%$, and we decided to test six levels between 0 and $4 \%$. There was a positive correlation between digestible energy (DE) fed and energy gain $\left(r^{2}=0.79\right)$. Likewise, there was a correlation between the protein fed and protein gain $\left(r^{2}=0.79\right)$. The higher the food ration, the more protein fed which resulted in higher protein gain and thus more growth. The efficiency of utilisation of protein was 0.37 , meaning that for each unit of digestible protein (DP) consumed the fish gained 0.37 out of it. However, the value for DE efficiency (0.27) was lower than that in studies on other fish species. For example, in gilthead seabream (Sparus aurata) the efficiency of utilisation of DE and DP for growth were 0.54 and 0.34 respectively (Lupatsch et al., 1998).

Therefore, a $4 \%$ body weight food ration was chosen to be suitable for milkfish cultured in Zanzibar when a diet containing $32 \%$ protein is used. 


\section{Water quality}

The experiment on feeding levels showed that the highest dissolved oxygen level in the morning was $99 \%$ at $1000 \mathrm{~h}, 103 \%$ in the afternoon at $1300 \mathrm{hrs}$ and $92 \%$ at 1600 hrs. High DO was observed in the 0 feeding level (unfed) whereas low dissolved oxygen was observed in the $4 \%$ feeding level throughout the experiment. Water quality monitoring for 24 hours showed that the dissolved oxygen and $\mathrm{pH}$ decreased with increasing feeding levels. Ammonia $\left(\mathrm{NH}_{4}^{+}\right)$concentration was higher in $4 \%$ feeding level than other levels showing that fish excreted more as the food ration increased. These concentrations did not vary significantly among feeding levels and remained below the critical levels. As the feeding levels increased, the level of protein also increased, which resulted in an increase in $\mathrm{NH}_{4}{ }^{+}$concentrations. Results of this research are in agreement with those of Kaushik \& Cowey (1991) who reported that the ammonia excreted by fed fish is directly related to the levels of protein intake.

\section{CONCLUSION}

Diet containing $32 \%$ protein at a daily feeding rate of $4 \%$ is recommended by this study to be used as a basis for the culture of milkfish (Chanos chanos) in Zanzibar. Once farming is underway, improvements in the diet can be made using different feed ingredients available or as a result of the information obtained in growing the fish to market size.

\section{REFERENCES}

Boonyaratpalin, M. (1997) Nutrient requirements of marine food fish cultured in Southeast Asia. $J$. Aquacult. Res. 151: 283-313.

Borlongan, I.G. \& Satoh, S. (2001) Dietary phosphorus requirement of juvenile milkfish, Chanos chanos (Forsskal). J. Aquacult. Res. 32: 26-32.

Bwathondi, P. O. J. (1982) The aquaculture of rabbitfish Siganus canaliculatus Park 1797 and problems of cage culture in Tanzania. Univ. Sci. J. (Dar Univ.) 8: 43-53.

Folch, J., Lees, M. \& Sloane, G. H. (1957) Simple method for isolation and purification of total lipids from animal tissues. J. Biochem. 226: 497-507.

Hardy, R. (1980) Fish feed formulation. In: Fish feed technology, FAO/UNDP Training course, Univ. of Washington, Oct- Dec 1978. ADCP/REP/80/11: pp. 233-240.

Kaushik, S. J. \& Cowey, C. B. (1991) Dietary factors affecting nitrogen excretion by fish. In: Cowey, B. \& Cho, C. Y. (eds), Nutritional strategies and aquaculture waste. Proceedings of the first international symposium on nutritional strategies in management of aquaculture wastes. University of Guelph, Guelph Ontario, pp. 3-19.

Lupatsch, I., Kissil, G. Wm., Sklan, D. \& Pfeffer, E. (1998) Energy and protein requirements for maintenance and growth in gilthead seabream (Sparus aurata L.). Aquacult. Nutr. 4: 165-173.

Mmochi, A.J., Mozes, N., Kite-Powell, H.L., Dubi, A.M., Gordin, H., Jiddawi, N., Kissil, G., Msuya, F. \& Mwangamilo, J. (2001) Design and preliminary results of integrated mariculture pond system (IMPS) at Makoba, Zanzibar, Tanzania. In: Richmond, D.M. \& Francis, J. (eds) Proceedings of the $20^{\text {th }}$ Anniversary Conference on Advances in Marine Sciences in Tanzania, $28^{\text {th }}$ June to $1^{\text {st }}$ July, 1999, Zanzibar, Tanzania. WIOMSA Book Series No.1: pp. 431-450.

Sumagaysay, N. S (1999) Feed ration for different sizes of wild and hatchery-bred milkfish (Chanos chanos Forskal). J. Aquacult. Res. 30: 789-792.

Sumagaysay N. S. \& Borlongan I. G. (1995) Growth and production of milkfish (Chanos chanos) in brackish water ponds: effects of dietary protein and feeding levels. Aquaculture 132: 273-183.

Sumagaysay N.S., Marquez F.E. \& Chiu-Chern Y.N., (1991) Evaluation of different supplemental feeds for milkfish (Chanos chanos) reared in brackish water ponds. Aquaculture 3: 177-189.

Zar, J.H. (1984) Biostatistical analysis, 2nd Edition, Prentice-Hall Inc., Englewood Cliffs, New Jersey. 718 pp. 